\title{
Recognition and Positive Freedom
}

David Ingram

Loyola University Chicago, dingram@luc.edu

Follow this and additional works at: https://ecommons.luc.edu/philosophy_facpubs

Part of the Constitutional Law Commons, Continental Philosophy Commons, Ethics and Political Philosophy Commons, and the Political Theory Commons

Author Manuscript

This is a pre-publication author manuscript of the final, published article.

\section{Recommended Citation}

Ingram, David. Recognition and Positive Freedom. Positive Liberty: Past, Present, and Future, , : , 2020. Retrieved from Loyola eCommons, Philosophy: Faculty Publications and Other Works,

This Book Chapter is brought to you for free and open access by the Faculty Publications and Other Works by Department at Loyola eCommons. It has been accepted for inclusion in Philosophy: Faculty Publications and Other Works by an authorized administrator of Loyola eCommons. For more information, please contact ecommons@luc.edu.

\section{cc) (†) $\ominus$}

This work is licensed under a Creative Commons Attribution-Noncommercial-No Derivative Works 3.0 License. (c) David Ingram, 2021. 
Recognition and Positive Freedom----David Ingram

\begin{abstract}
:
A number of well-known Hegel-inspired theorists have recently defended a distinctive type of social freedom that, while bearing some resemblance to Isaiah Berlin's famous description of positive freedom, takes its bearings from a theory of social recognition rather than a theory of moral self-determination. Berlin himself argued that recognition-based theories of freedom are really not about freedom at all (negatively or positively construed) but about solidarity, More strongly, he argued that recognition-based theories of freedom, like most accounts of solidarity, oppose what Kant originally understood to be the essence of positive freedom, namely the setting of volitional ends in accordance with an individual's exercise of his or her own reason, apart from social authority.

In this chapter I argue that recognition might describe an essential social condition of positive freedom, or moral autonomy, as Kant and Berlin understand that term, but only with qualification: Only if recognition doesn't imply a strong state of social solidarity, understood as a psychological state of identifying with, viz., feeling totally at home with and completely affirmed by, one's society, and instead assumes only a weak form of democratic civic solidarity, can it function as a category of social freedom, and then only in the narrow sense of political freedom. To the degree that the different institutionalized forms of recognition in modern democracies compete with each other, social freedom will presuppose a second-order recognition of society's affirmation of their freedom by those whose identities are invested in these forms, to wit: that such forms are or can be sufficiently harmonized with each other by means of judicious government policies and constitutional safeguards. Recognition that one is not overly dominated by a given social role or social expectation in living one's life can enable one to become rationally reconciled to society and its primary recognition orders in a way that can be socially freedom-affirming. Detached in this way from any positive solidarity with society, recognition-based social freedom cum recognition of non-domination might also (perhaps better) be conceived as a species of negative social freedom. I conclude that rational reconciliation remains at best an imperfectly achievable goal in modern societies marked by basic constitutional and institutional tensions.
\end{abstract}

\title{
1. Introduction: Berlin
}

The concept of negative liberty that was famously memorialized by Isaiah Berlin refers to "the ability to do what one wishes," or "to be left to do or be what he is able to do or be, without interference from other persons" (Berlin 1969: 121-2, 139). The concept of positive liberty, by contrast, refers (again citing Berlin) to the "source of control or of interference that can determine someone to do, or be, this rather than that" (Berlin, 122). Classical examples of positive freedom mentioned by Berlin include subjective conditions of agency, such as selfcritical reasoning and autonomous willing. These conditions, he notes, must be realized, in the 
first instance, from within the will of the lone agent (as Kant described the truly moral self, whose own reason prescribes the universal laws of free action). However, Berlin adds that proponents of positive freedom from Aristotle to the present day have understood that selfdetermination, however it is conceived, depends on intersubjective and objective conditions for its realization. So understood, positive freedom must also be realized, in the second instance, from within the collective will of the political society with whom the individual solidaristically identifies (as Rousseau describes the truly free citizen of a democracy, whose identification with his fellow citizens prescribes their common aims and guarantees their harmonious cooperation). Further specifying these intersubjective conditions, and anticipating contemporary theorizing about the multicultural politics of recognition developed most famously by Charles Taylor and Axel Honneth, Berlin observes that, in stark contrast to Kant's subjectivistic understanding of positive freedom, Edmund Burke and post-Kantian philosophers within the German Idealist tradition held that:

I am a social being in a deeper sense than that of interaction with others. For am I not what I am, to some degree, in virtue of what others think and feel me to be? . . . [S]ome, perhaps all, of my ideas about myself, in particular, my sense of my own moral and social identity, are intelligible only in terms of the social network to which I am (the metaphor must not be pressed to far) an element. The lack of freedom about which men or groups complain amounts, as often as not, to the lack of proper recognition (Berlin 155-my stress).

In a footnote Berlin pointedly observes that this "socialized" version of Kant's doctrine of human freedom is "almost its opposite," in that "Kant's free man needs no public recognition for his inner freedom" (Berlin 156n1). Indeed, he remarks that because "I am in my own eyes as others see me ... this is the most heteronomous condition imaginable" (ibid). For "if I am not so recognized, then I may fail to recognize, I may doubt my own claim to be a fully independent human being" (Berlin 157).

Writing at the height of the Cold War, Berlin was keen on showing that the tendency to lump together positive freedom, understood as an individual exercise of rational decision-making, and the psychological need to feel that one's needs, values, and identity are in harmony with society through solicitation of positive affirmation by one's consociates jeopardized the unique essence of political liberty, understood as a natural limit to totalitarian governments. As against the notion that society and state must perfect one's freedom and identity in a social direction, Berlin again and again appeals to the common core of negative and positive freedom as non-domination, viz., being free to act and to control one's train of practical reasoning free from the interference of others. Like George Orwell, he burnishes the scalpel of conceptual analysis to argue that even labeling positive liberty as a kind of solidarity-ensuring social freedom disingenuously amounts to dialectical double-speak in which it becomes permissible to "force someone to be free," to paraphrase Rousseau's famous assertion about the need of all to conform their private wills to the general will or common good ostensibly embodied in the wise legislator's proposals for democratic referendum (Berlin 148). By this route, liberty comes 
to mean nothing more than allowing oneself to be coerced by a public law or public opinion that is judged to be more rational and correct in assessing one's own good than one's own fallible deliberation.

What interests me about Berlin's perceptive and subtle diagnosis of the dialectic of individual autonomy and socially conditioned identity, about which I shall have more to say below, is his insistence that freedom in both its positive and negative forms reduces to a kind of negative social freedom: non-domination. It is the social domination implicit in totally identifying one's one identity in self-sacrificing solidarity with society that leads him to conclude that recognition is "misleadingly --called social freedom" (Berlin 158).

The essence of the notion of liberty, both in the "positive" and "negative" senses, is the holding off of something or someone- of others who trespass on my field or assert their authority over me ... The desire for recognition is a desire for something different: for union, closer understanding, integration of interests, a life of common dependence and of common sacrifice (Berlin 158).

I agree with Berlin that the common essence of freedom is non-domination: the determination of who I am and who we are should not be imposed on me (us) from the outside. ${ }^{1}$ But is Berlin right that the desire for recognition necessarily opposes the idea of freedom as "the holding off of something or someone"? My own view is that Berlin is mistaken on this point. Supposing that his understanding of freedom is roughly correct, his identification of recognition with solidarity is not. At the very least, a desire for "closer understanding, integration of interests, and a life of common dependence" can sometimes require political disagreement and nonconvergent forms of cultural understanding, non-domination of particular social aims and interests, and independence from particular social institutions. Once we parse recognition into its several modalities, focusing especially on the modern idea of mutual respect for others as free and equal citizens, it becomes apparent that freedom as he understands it depends on civic solidarity, or public recognition of the independence of fellow consociates who remain conjoined in democratically shaping their collective identity and freedom.

Berlin himself does not dispute that this kind of publicly acknowledged attachment to a shared democratic ethos comports with freedom. His failure to see the connection between recognition, solidarity, and social freedom might well be attributed to his desire to achieve conceptual clarity at all costs. But even he concedes that "social and political terms are necessarily vague," so that "the attempt to make the vocabulary of politics too precise may render it useless" (ibid). Berlin commits this last vice when he opposes the inner and outer sources of volition and identity. Thus, a critic of Berlin might rightly point out that the concept of positive freedom Berlin deploys presumes that the practical reasoning of individuals

\footnotetext{
${ }^{1}$ Although most contemporary accounts of recognition focus on its contribution to psychological wholeness and well-being, some accounts (Hegel's included) emphasize its objective and, for lack of a better word, ontological contribution in constituting agency (self-certainty) and intentional; viz., meaningful and purposive action.
} 
mysteriously sprouts up out of nowhere. Such an externally unconditioned source of choice would, however, not be internal, if what is meant by that term is personal as opposed to impersonal (viz., universal, transcendent, and unchosen). Berlin is too well informed by the facts of socialization to accept this relic of Kantian metaphysics, which in fact obscures the very meaning of individual freedom. Nonetheless, by insisting that "it is important to distinguish between liberty and the conditions of its exercise" (Berlin liii) he seems indeed to have rendered the concept of positive liberty rather useless through an all-too-precise abstraction from its social conditions.

This criticism of Berlin is forcefully advanced by Axel Honneth, who today stands among the most eloquent defenders of a recognition-based theory of social freedom. As Honneth observes, Berlin's concept of liberty (in both its negative and positive formulations) is too thin, normatively speaking, to enable it to stand alone as the sole premise supporting Berlin's own defense of political liberalism. Political liberalism, which extols political freedom of thought and action, has a distinctive genealogy that distinguishes it from pre-modern political ideologies. Its supreme preference for individually exercised negative freedom reflects a cultural preference (something akin, perhaps, to Charles Taylor's notion of a "strong evaluation") that arises not from pure reason but from a shared form of life. The liberal form of political life and its presumption of cultural value pluralism both conditions, and is conditioned by, moral positive freedom. Both political pluralism and positive moral freedom presuppose a prior acceptance of a more basic principle of social recognition: Each person should recognize the right of plural cultures to exist free from external social domination by other groups, and more specifically, the right of any person to participate in cultural groups wherein their values and identities are nurtured and affirmed by the groups in question. Honneth sums up this argument in the following pithy formulation:

[Y]ou can't defend a radical, far-reaching notion of negative freedom on the one hand and emphasize the right of the individual to live in his or her own culture on the other. The latter practice is only possible on the condition that some people's negative freedom is reduced enough to ensure the continued existence of cultural communities (Honneth 2007c: 251).

In sum, Berlin's concept of liberty, in both its branches, presupposes for its useful political application liberal constitutional institutions that reflect a prior social recognition on the part of citizens of (1) their mutual individual legal and moral rights to freedom of thought, action, religion, and association and (2) their mutual social freedom from of societal (group- or institutionally-based) domination.

In response to this irrefutable demonstration, a defender of Berlin's view that recognition is not a variety of freedom might still fall back on Berlin's analytic distinction between an abstract concept of freedom and its concrete, real-life conditions. Indeed, in the most recent adumbration of his theory, Honneth himself follows Berlin in distinguishing negative (legal) freedom and positive (moral) freedom ---the latter rechristened as reflective freedom---from a recognition-based conception of social freedom. However, deploying a more dialectical 
terminology, Honneth argues (following Hegel) that neither abstract negative freedom, which finds preeminent expression in the form of individual legal rights, nor abstract positive freedom, which finds preeminent expression in individual autonomous moral judgements of right and wrong and ethical valuations of authentic and fulfilling existence, are sufficiently meaningful, useful, and rational apart from the concrete social interactions and deliberations that serve to critically and consensually determine them. Following this Hegelian method of developing conceptual content by situating abstract terms within progressive conditions for specifying their actual, concrete force and meaning, and keeping in mind the democratic tenor of social life in modern liberal society, we can tentatively conclude that the concrete, constitutionally institutionalized, critical exchange of opinions among persons who recognize themselves as free and equal, both morally and politically, enables such persons to become freer in the positive sense of the term (Ingram 2018: 47-84).

At this point it behooves us to recall Berlin's linkage of positive freedom and freedom from domination. Minimally, enjoyment of equal negative freedom from interference by tyrannical democratic majorities must be constitutionally guaranteed in order to secure moral and political freedom for all citizens. But more than civil liberty is required to protect positive freedom, which becomes obvious once we take account of the fact that persons who possess the necessary capabilities to deliberate and make informed choices about legislators and government officers can decide policies that impact the lives of those who lack these prerequisites. The effects of these policies on the politically marginalized is experienced by them as an external imposition, shaping their choices without their input or consent. The poor, the uneducated, the overworked, and the marginalized thus experience a lack of positive freedom in controlling their lives. They might experience social domination of a quasi-personal kind (e.g., the hegemony of this or that class or group with respect to political power), but they invariably experience social domination of an impersonal, structural kind.

Recognition theory cannot illuminate this structural injustice as a species of overt discrimination and disrespect, however much it underscores the invisibility of the socially marginalized, or their lack of recognition simpliciter (Bohman 2007). But it can explain this injustice indirectly, as a violation of mutually recognized expectations regarding the normal and proper functioning of economic, educational, familial, and political institutions (see Part 3 below). Indeed, the mutual expectation that all persons have opportunities and capabilities to participate as active citizens in the lives of their communities presupposes not only that they have the requisite capabilities and opportunities, but also that they have the freedom to take advantage of these capabilities and opportunities without threat from another kind of structural domination, which might best be described as the tyranny of economic and legal systems over relationships pertaining to familial intimacy and public discussion. Freedom from this kind of domination, I argue, also intersects social recognition of civic solidarity, but in a secondary way, as reconciliation with society as a community of mutually supportive communities, to paraphrase John Rawls.

2. Solidarity and the Circularity Problem 
I shall have more to say about institutional domination and recognition as social reconciliation below. Suffice it to say, it makes sense to speak of mutual recognition of persons' freedom and equality as a social condition that enhances an individual's positive freedom only if such recognition is extended to all and only those who properly merit this distinction. Racists, sexists, and other intolerant demagogues diminish democratic political life by silencing the critical voice of others. As Honneth himself states the matter in the passage quoted above, the large society of liberal democrats has a right and perhaps a duty to suppress or curtail the freedom of illiberal groups.

Here we have an appeal to civic solidarity---to a widely recognized and shared commitment to a set of liberal democratic values and a liberal democratic identity--- against the negative freedom and social domination of extreme dissenters to civility itself. What distinguishes this coercive appeal to solidarity from the totalitarian variety of concern to Berlin is not its alleged foundation in a higher social freedom. Both totalitarian and liberal-democratic forms of solidarity appeal to a harmony of wills and identities; in this regard even liberalism goes beyond "mere respect and tolerance" and includes the realization that "the aims of my own life are something that [others'] abilities have made possible or enriched" through multicultural and multi-perspective dialog (Honneth 2007d: 257). The difference between illiberal and liberal democratic solidarity lies in the source and structure of the harmony. In traditional communities ordered according to what is commonly perceived to be a necessary and natural social hierarchy, persons may esteem those within their rank, viz., they may regard their accomplishments and values as of approximately equal worth in comparison to their own; however, lower ranks of persons are held in contempt by persons occupying higher stations who possess something like the status of undiminished dignity and nobility,

Secularization, which undermines metaphysical belief in the objective and eternally preordained nature of society by revealing its human-made character, endows all humans with equal dignity as autonomous individual contributors to their society's order---the principle of recognition underwriting egalitarian democracy (ibid, 259-61) Modern totalitarianism seeks to restore the kind of objective rank order found in traditional societies on the basis of race, class, or some other ground. Totalitarian solidarity presupposes hegemonic cultural homogeneity and is generated by government brainwashing or authoritarian familial socialization. This uncritical (heavily scripted) identification of persons with a set of concrete collective goals and their corresponding social role expectations contradicts the critical (free and self-reflective) identification of persons with the liberal, egalitarian goals and social role expectations that define democratic civic solidarity. The latter presupposes cultural value pluralism and is generated and maintained by inclusive communication and critical challenges by others within political fora.

The reference to political fora suggests a further difference between the two contrasting forms of social solidarity, in that the liberal form institutionalizes a distinctively secondary, political order of recognition that reflects on the primary orders of recognition that compose economic, familial, and civic life. The institutionalization of formal democratic procedures and abstract rights of citizenship undermines dogmatic adherence to rigidly 
circumscribed goals and social identities, and reflectively provokes reinterpretations of the procedures and rights themselves.

This distinction between liberal democratic solidarity and totalitarian solidarity explains recognition theory's unique solution to the vicious circle alluded to in Berlin's account of solidarity that seems to render solidarity unsuitable as a form of social freedom. Totalitarian solidarity maintains itself through a relatively closed system of mutually reinforcing patterns of familial socialization and social authority. The seamless integration of all aspects of individual and social life guarantees that the scope for individual choice that has not been socially preprogrammed by society will be very limited. In comparison to totalitarian solidarity liberal democratic solidarity maintains itself through a relatively open network of institutions and associations that possess their own distinctive ---simultaneously complementary and conflicting ---values and norms. These institutions and associations make competing demands on their individual members, who are then forced to take up a critical "outsider" stance with respect to each of them. These individuals must then switch from playing the institutional role of obedient and loyal insider (good employee, good friend, etc.) to playing the reflective political role of good citizen-social critic. In this instance their exercise of personal positive freedom breaks out of the circle of institutionally programmed options to include higher level (reflective), secondary, democratic deliberation on how best to politically harmonize them.

\section{Social Freedom as Reconciliation to Modern Society}

Honneth's own understanding of how different recognition orders place competing demands on persons' primary exercise of choice that compel higher-level exercises of democratic social freedom illustrates the point I am making. Just as importantly, it recalls a distinctly Hegelian conception of social freedom, understood as social reconciliation, or higher-order political recognition of the harmonious complementarity of different recognition orders.

In earlier formulations of his theory Honneth distinguished three major valences of recognition that secure general anthropological conditions of individual agency, personal integrity, and fulfillment: love (or emotional affirmation of one's personal desires and capabilities), respect (cognitive affirmation of one's equal dignity as an autonomous agent), and solidarity (affirmation of one's sharing common, culturally shaped identity with others or, in a rather different vein, one's contributing to the cooperative achievement of collective goals through work). Love and solidarity are universal social goods that are necessary for realizing personal agency and fulfilment in any society. By contrast, equal respect for the inherent dignity of each person is a construction of modern liberalism (replacing traditional codes of nobility), which eventually modulates the modern understanding of love and solidarity as well.

In his latest theory of recognition, Honneth moves beyond philosophical anthropology to a genealogy of modern society, whose presupposition is a distinctly liberal democratic conception of social freedom. Hegel's memorable depiction of human history as a "struggle for recognition" that formed the title of Honneth's inaugural treatise on the subject is now drawn more closely to Hegel's own characterization of that struggle as a struggle for individual 
freedom. The argument of Freedom's Right (Das Recht der Freiheit) hews closely to the argument of Hegel's Philosophy of Right (1821): negative freedom from constraint, objectively institutionalized in the form of individual legal rights, and positive (or reflective) freedom, subjectively instituted in individual moral conscience and existential choice, are both conceived as socially undetermined abstractions. The former, which is a product of modern liberalism, and the latter, which is of ancient vintage, find their ground in three recognition-based institutional practices (Hegel's ethical sphere's [Sittlichkeit]) that comprise social freedom: intimacy (the uninhibited expression of personality), economic cooperation (the mutual satisfaction of need), and political life (the determination of freedom and the coordination of social functions around common ends).

For the purpose of illustrating the connection between social freedom and reconciliation, the main shift that motivates my interest in Honneth's pivot toward freedom as the defining feature of modern struggles for recognition pertains to the progressive democratization of all spheres of life. $^{2}$

I wouldn't speak of a formal theory of the good anymore, but rather of a historically informed concept of ethical life (Sittlichkeit). . . I claim that all these spheres of freedom must mesh freely with each other [zwanglos ineinandergreifen] as democratized practices to make a realization of ethical life possible. I do not ascribe to the idea that the realization of these dimensions of freedom would automatically enable the unhindered self-realization of the individual. . . . (Honneth 2015: 266).

For we who live in modern society, freedom has become our most important end---more important than even individual self-realization; and we become free only when the democratic principle of mutual egalitarian recognition is extended into all spheres of life in a manner that affords us a possibility for harmoniously integrating them within our own lives. To elaborate further on the first point made in the passage cited above, in the last fifty years we see a democratic trend within familial relationships insofar as gender-based roles within the family have increasingly broken down, along with the authoritarian patriarchal pattern of decisionmaking. Not only adult family members but children participate as equals in family planning decisions. Turning to economic relationships, the growth of unions and worker management, coupled with market regulation and social welfare policy, appear to support Honneth's contention that the market has undergone a process of "communitarianization,"an emerging awareness of the rights and duties of all stake-holders in the economic life of the nation. (Honneth 2015: 272). Political life, too, has become more inclusive, with disaggregated forms of citizenship that allow legal residents to vote in municipal elections. All of these developments would seem to suggest that "sooner or later an appropriate [democratic] model of the family and of a socialized market has to be accepted" (Ibid.: 281) along with recognizing that

\footnotetext{
${ }^{2}$ Honneth's penchant for anthropological speculation is evident in his recent claim that the democratization of life culminates an archaic need for reasoned justification (Honneth 2015: 264).
} 
"decisions within the nation state are [to be] made under inclusion of the hitherto excluded other" (Ibid.: 278).

As for the second point made in this passage, Honneth appears to acknowledge that democratizing life within each social sphere taken separately is not enough to secure social freedom. Also required is their second-order democratic harmonization. Social freedom can only be achieved under the broader aegis of a political reconciliation of, and a political reconciliation to, all spheres of society, taken as a whole. To paraphrase Hegel's definition of reconciliatory social freedom as "being at home with oneself in another," also needed is a higher-order recognition of "a diversification of solidarities, namely everywhere, where freedoms are realizable together as a form of co-existence and socially being for others" (Ibid.: 276).

An example of this kind of mutually transformative, cross-fertilizing democratic harmonization is reflected in Honneth's claim that if "aptitudes and practices of democracy are developed [in the family], then these aptitudes and practices can be "further practiced and developed in other higher forms and in other spheres" (Ibid.: 270). To a certain extent, the family remains the locus classicus for collectively deliberating about how best to balance the different demands of work, politics, and intimacy, just as it remains the locus classicus for conflict resolution through democratic negotiation. Therefore, it is the micro-laboratory for developing democratic dispositions and aptitudes in advance of developing democratic workspaces and democratic public spheres.

\section{Unfreedom in Modern Society}

As the last point in the passage makes clear, we should not expect that the democratization of sub-dimensions of social freedom taken separately will automatically lead persons to feel selffulfilled and socially empowered unless they can also harmonize these sub-dimensions in their personal lives. The language of reconciliation further suggests that more is involved in being socially free than successfully balancing the demands of work, intimacy, and public life to one's personal satisfaction. Inner harmony cannot be subjectively experienced, let alone willed, if objective reality is discordant. What if the recognitive expectations generated by each dimension of social life clash in a way that makes reconciliation objectively and subjectively impossible? In acknowledging this possibility, Honneth involves the very different language of prioritization.

which of the various relations of recognition is to be preferred in a case in which they raise conflicting claims cannot in any way be decided in advance .... We are obligated in concrete situations to accord others recognition in a mode that corresponds to the respective kind of social relationship at issue; but in the case of a conflict, we have to decide which of our bonds is to be granted priority (Honneth 2007b: 141). 
Prioritization implies selection; enjoyment of one kind of social freedom will require not enjoying another kind. ${ }^{3}$ Taken in the abstract, within a specific kind of recognitive relationship, such as friendship, my freedom to love and be loved in return does not conflict with, say, my freedom to earn a living as an employee of a firm. Taken in the concrete, however, the time I spend enjoying intimate freedom is diminished in proportion to the time I spend in meeting my material needs. ${ }^{4}$

All of this raises a worrisome question about whether or not society's competing recognition orders can be sufficiently reconciled so as to enable persons to achieve a higher-level reconciliation with society as on the whole socially empowering as distinct from socially oppressive or alienating.

In modern liberal society conflicts between different parts of one's personal identity are normal rather than exceptional. ${ }^{5}$ And this raises the problem of one part coming to dominate other parts to the point where persons feel alienated from both themselves and from others. Honneth himself gives many examples in which one kind of social relationship crowds out another kind in such a way that the parties involved experience an overall diminution of their freedom. Family law, for instance, has evolved in such a way as to increasingly protect (and thus enhance) the equal freedom of spousal partners with respect to such matters as childrearing, but an obsessive focus on the family as a contractual relationship, which typically happens during separation and divorce proceedings, can elevate the question of custodianship over children to such a high point that it occludes the parental care of children---as for example was depicted in exemplary fashion in the film Kramer $v$ Kramer. Taking Honneth's interpretation of this film at face value (Honneth 2014: 90-91), one gets the impression that the embattled spouses depicted in the film were themselves victims of an overly juridified construction of the family, having no recourse but to submit to the coercive game of threat and counter-threat promoted by their lawyers and abetted by an adversarial legal system. True, a more accurate interpretation might be that the parents themselves simply exercised poor judgment in allowing their legal battle to interfere with their childcare responsibilities. Be that as it may, there can be little doubt that embattled parents in custody cases are caught in a

\footnotetext{
${ }^{3}$ For Honneth, highest priority must always be accorded to moral relationships enjoining universal respect for "equal rights to autonomy" (Honneth 2007b: 141).

${ }^{4}$ See Marx's contention that the amount of time spent on "necessary labor" requisite for fulfilling human needs ---not to mention the time spent on surplus labor requisite for producing profits---would be eliminated (in the latter instance) or reduced (in the former instance) within a fully developed communist society wherein each person would be free to develop his or her powers in an all-around way.
}

${ }^{5}$ I discuss one particular dilemma ---the self-subordination/social recognition paradox highlighted by Serene Khader---that women in societies transitioning toward modern economic relations encounter when they access microcredit in Ingram (2020). 
dilemma ---or rather multiple dilemmas---endangering their own and their children's freedom. For, aside from the impending dissolution of an intimate relationship, each party to the dispute must weigh the ethical propriety of using their children as expert legal witnesses who might testify on their behalf against someone they love. In the final analysis, each party must decide how far one kind of freedom-enhancing social relationship (enabling the negative legal freedom to enter into and later dissolve marriage/civil contracts) will be allowed to interfere with another kind (such as enabling the positive moral freedom to expressively expand and enrich one's identity in a committed loving relationship or the social freedom to develop one's selfconfidence and other agential capabilities as a child).

No doubt, a judicious exercise in our positive freedom is necessary to ensure that the competing demands of public life, work, and intimacy are in sync with one another, and that a healthy respect for one's rights do not come into conflict with one's ethical duties of care, as Carol Gilligan and many other feminists writing on relational autonomy have pointed out. However, the problem of cultivating our social freedom, Honneth reminds us, is at bottom a social and political problem, not a personal, ethical one. This is illustrated by an enduring trope that critical theory in the Marxist-Hegelian tradition has invoked for almost two hundred years: the destructive intrusion of capitalist market relationships into other areas of public and private life. As Honneth remarks, since the advent of neo-liberal (post-Fordist) area, capitalist market relationships have devolved in a decidedly anti-communitarian, anti-social democratic direction, which in turn has threatened the democratizing tendencies at work in the family and in the political sphere.

In all these aspects of socio-cultural democratization and development of a democratic ethical life, the family has improved considerably as an institution, while at the same time facing massive socio-economical structural challenges. The massive pressure for mobility and flexibility .... challenges and to a large extent undermines the practices of freedom and democratization. One might even speak of an invasion of work onto the family, where mothers and fathers are forced to meet such demanding and fatiguing work conditions that they are forced to bring them into the private sphere, and thus lose the ability to fully benefit from the cultural and moral progress of the last 50 years. (Honneth 2015: 271).

\section{Defending Social Freedom: Recognition and Critical Theory}

The question I raised at the outset of this chapter is whether the peculiar interpretation of recognition as social freedom can be explained or understood in a way that is not fundamentally question-begging. First, it might be argued that whatever reasons persons have for identifying or not-identifying with an enabling social order will be conditioned by that very same order. Persons may feel loved, respected, and esteemed for lack of knowledge about alternative experiences of love, respect, and esteem that might persuade them to think 
differently. ${ }^{6}$ This circularity in conditioning---the absence of an independent ground for reasoning about the freedom-enabling capacity of the social order-makes it impossible to decide whether the social order in question enables/enhances or hinders/diminishes one's positive freedom. The resulting identity between society and individual will therefore undermine any potential for independent social criticism, thereby reinforcing Berlin's postulation of an essential link between social recognition/solidarity and totalitarianism/domination.

Second, and conversely, it is not clear how, within a non-totalitarian society in which individuals remain free to criticize society, simply relying on experiences of misrecognition or non-recognition can be a sufficient reason for judging the absence of positive/ social freedom. People experience conflict between their personal identities and prevailing societal norms for different reasons. A white male supremacist might feel caged in by a society that has come to celebrate racial equality. Is his experience best described as a lack of social freedom or as misperception on his part of the limitations of his own personal belief system? Is he in some non-experiential sense socially free because he lives in a non-racist society but ignorant of that fact due to the compulsions of prejudice? Contrast his case with a black woman who feels caged in by a society that in her own experience, and evidenced by objective statistics, has not fully lived up to its anti-racist and anti-sexist ideals. Here, the experience of not having one's situation, perspective, and needs fully recognized reflects a demonstrable lack of social recognition and, therewith, a diminution of one's social freedom (or psychological discomfort in navigating social relationships with police, doctors, service providers, and others).

What these examples suggest is that something like a normative theory of social freedom that is less tethered to uncritical interpretations of societal norms and personal experiences will be needed to distinguish reasonable from unreasonable forms of social contentment/discontent. However, short of invoking a discredited notion of transcendent reason, such a theory will invariably find itself enmeshed in some version of the circularity problem noted above; whatever norms recognition theory might uphold in condemning racism, sexism, and other forms of privilege will ultimately be ones that a given society recognizes but imperfectly embodies in its historically evolving institutions and membership.

Third, alternatively, if we postulate a more dialectical form of social criticism that avoids the circularity problem, we run the risk of eliminating the second-order recognitive conditions requisite for social freedom in the first place. For example, if the different ways in which we seek recognition from (identification with) others occur within social relations that are structured by antagonistic institutions and not the unified totalitarian state system that worried Berlin---a hypothesis that seems especially pertinent to modern, liberal societies---then it might

\footnotetext{
${ }^{6}$ Notice, too, that if they feel misrecognized and disrespected, they might misidentify the reason for their feelings (for example, by blaming persons rather than societal norms). Does the resentment a financially dependent homemaker feels toward the domestic breadwinner clearly evoke the thought that one isn't being properly respected as an independent claimant to entitlements and liberties? Or does it evoke the thought that one isn't being properly esteemed for contributing to the household economy or that one isn't being properly loved. The latter possibility doesn't necessarily stand as an indictment of social injustice, whereas the former very likely does.
} 
seem that social freedom is simply impossible. Individuals will not possess a stable, coherent, or at any rate fully integrated personal identities and will feel at home with themselves, their society, and the particular social roles they play for only those fleeting moments of their lives whenever playing these roles does not clash with playing their other socially recognized roles. Furthermore, at the macro-societal level, instead of social harmonization among antagonistic institutions being affected through voluntary recognition of the mutual solidarity among persons inhabiting these spheres, social coordination will be mechanically (or coercively) imposed through legal and market systems whose complex functioning and abstract nature will be experienced by some of those subject to them as alien, reifying and freedom-denying. Here, a functionalist, rather than identitarian, totalitarianism threatens not just social freedom and positive moral freedom, but individual negative freedom and its kindred concept, freedom from social domination. ${ }^{7}$

Fourth, and somewhat paradoxically, critical resistance to social domination will then seem to depend upon the postulation of a utopian desire for social freedom that is nowhere to be found within society itself, even in individuals' exercise of positive moral freedom, but only within individuals' pre-social instincts---the solution proposed by the founding members of the Frankfurt School. ${ }^{8}$ Even if we replace the Freudian drive theory that informs this utopian social critique with a theory of socialization that is directly premised on some account of social recognition, as Honneth does in drawing from the object-relations theories of Donald Winnecott and Jessica Benjamin, it seems that the most perfect and emblematic form of social (recognitive) freedom, and the form that Honneth himself posits as foundational for all other forms 9 ---familial love---designates, by Honneth's own account, at best a partial expression of social freedom and one, moreover, that cannot be extended to other domains of social interaction without violating their proper social functioning. Indeed, extending the exclusive form of caring and loving appropriate to intimate relationships to other social groupings rather threatens illiberal forms of patriotism and group loyalty, such as those associated with virulent nationalism and ethnocentrism (Hedrick 2019 174-76).

The aforementioned catalog of concerns challenging the viability of a recognitive account of social freedom can be accommodated, if not dismissed, by the following rejoinder.

\footnotetext{
${ }^{7}$ Marx's classical account of commodity fetishism in the first volume of Capital has often been regarded as the touchstone for this diagnosis of capitalism. Drawing from Weber's cultural analysis of conflicting value spheres and Durkheim's functionalist account of contractual bonds in modern society, first-generation critical theorists such as Adorno and Horkheimer proposed that what little genuinely free social relations had ever existed among autonomous individuals had long been extinguished by modern forms of totalitarian administration and social conditioning. Something of this pessimistic diagnosis survives in Habermas's later treatment of the "colonization of the lifeworld" by economic and administrative subsystems.

${ }^{8}$ In Dialectic of Enlightenment (1944), Adorno and Horkheimer (drawing from Nietzsche and Freud) argue that the iconic Kantian understanding of positive freedom, understood as moral autonomy, or rational suppression of inclination, is itself a product of social domination: the introjection (internalization) of punitive social authority in the form of "individual conscience." They and other critical theorists of their generation (notably Marcuse) subsequently proposed less self-centered, less reason-dominated modes of aesthetic freedom incorporating mimetic (imaginative) reconciliation with nature in its sensuous particularity.

9 "[w]e can safely assume that all three forms of relation-to-self [self-confidence, self-respect, and self-esteemD.I.] can develop in unison through the internalization of parental care, and are only experienced later as distinct aspects of one's life by gradually differentiating various partners in interaction" (Honneth 2012: 205).
} 
In order to parry the first two concerns noted above, regarding the circularity charge, I concede Berlin's point that robust, recognition-based social freedom is antagonistic to positive moral freedom. However, I maintain that a less robust recognition-based social freedom is at least theoretically conceivable. Non-totalitarian, liberal democratic social orders approximate this genuine kind of social freedom better than illiberal, non-democratic societies because they permit persons who exercise different social roles relative to different schemes for coordinating action to critically evaluate any given social role's limits and possibilities for actualizing social freedom in light of what other social roles promise in this regard. In other words, the forms of solidarity Hegelians defend as most definitive of recognition-based social freedom do not coalesce into the kind of totalitarian identity that worried Berlin. To illustrate my point, we can compare the different ways in which members of families can enhance or hinder each other's freedom through loving / caring relationships with the way members of political society (citizens) can enhance or hinder each other's freedom through democratically negotiated legal relationships. We can ask whether families should embody more democratic freedom or whether political and legal relations should embody more nurturing freedom. And we can ask whether one kind of freedom-enabling social relationship has become so pervasive as to endanger other kinds of freedom-enabling social relationships. For instance, we can ask whether market transactions mediated by employee/employer or producer/consumer roles have penetrated into other, non-economic areas of life and then ask whether this is good or bad for actualizing social freedom in our lives as a whole.

This response to the circularity objection, of course, does not explain why the kind of differentiated liberal democratic society extolled by recognition theorists as actualizing social freedom should be so esteemed. Comparative assessments of the progressive nature of this kind of society relative to its predecessors within a particular historical path of development (e.g., European history) are still question-begging (Allen 2017), but similar assessments can be made across global cultures in a provisional way to the extent that tendencies toward widespread resignation to, if not voluntary acceptance of, capitalist economies and liberal democrat institutions can be confirmed.

As for the third and fourth objection, I argue, following second- and third generation critical theorists, that modern, market-driven, liberal democratic societies are not totally reified administrative economic systems. As I noted above, the kinds of social roles and potentials for social freedom embedded in one sphere of action provide a critical standpoint for reflecting on the social roles and potentials for freedom embedded in other spheres in a non-reductive way. We therefore do not need to appeal to psychological theories about emancipatory drive potentials in order to explain critical resistance to reifying tendencies. Likewise, a theory of socialization that sensibly emphasizes the importance of social recognition and communication need not privilege one kind of social recognition and social freedom as exemplary for all social action spheres tout court. For example, we can insist that competitive market relationships should also live up to standards of social responsibility with regard to protecting a shared environment and guaranteeing a decent income for all---goals associated mutual caring--without violating standards of social esteem based on competitive success and achievement. In theory, at least, we can conceive a non-reductive mediation of social action spheres conducive to harmonious societal functioning. Conversely, we can criticize and resist the dysfunctional domination of some institutionally-based social relationships over others. More positively, we 
can advocate for policies that felicitously integrate and harmonize all such social relationships, so that we can come to reconcile ourselves to the entire social order as a recognizably progressive realization of social freedom for all.

Having suggested the theoretical possibility of a modest, recognition-based account of social freedom, I now conclude by surveying some of the obstacles to actualizing reconciliation in practice. Some of these obstacles were trenchantly discussed by Marx in his critique of capitalism and, more generally, of monetized market societies. For Marx, Hegel's "rational" solution to the conflictual (antagonistic) and atomizing dynamics of civil society---the sphere wherein individuals recognize each other primarily as legal claimants to negative liberty--required that Hegel logically adduce for its solution the idea of mediating institutions, such as corporate political representation of government, landed, and occupational groups (the estates), bureaucratic welfare agencies (the Polizei), and business associations incorporating employers and employees (the corporations) that would ostensibly promote the common welfare. Marx was visionary in criticizing the various forms of class domination and alienation that these mediating institutions concealed and rightly debunked the paternalism implicit in Hegel's bureaucratic welfare administration as itself furthering the particular interests of a professional class (Marx 1994a). Ultimately, given the unresolvable problem of unemployment and poverty in capitalist society, Hegel himself believed that individuals would experience themselves as socially free only when acting in their capacity as citizens who could participate (in however limited and virtual a manner) through political life and representative legislative bodies that, he optimistically believed, could fashion a general will oriented toward the national good.

Marx believed that this political form of emancipation, even when instituted in a liberal democratic constitution, fails to bring about authentic human (i.e., social) emancipation (Marx 1994b). If we reject Marx's revolutionary proposal to abolish capitalism and, more radically, the distinction between a civil society of self-interested, private individuals and a constitutional state of socially-interested, public citizens, then a more social-democratic version of Hegel's political solution to effecting reconciliation remains our only alternative. In that case, we must ask how much our competing institutional roles of active participant in political life, passive recipient of government entitlement, economic producer/provider, consumer, personal caregiver, etc. can be harmonized in a manner conducive to "being at home with ourselves in an other." We must ask, in other words, whether there is reasonable hope that the contradictions among competing demands of modern society and the all-too-pervasive domination of economic and legal relationships in our private and public lives can be significantly reduced over time.

My tentative answer to this question is: not much. We have too little reason to hope that market systems that distribute recognition based on success, even when buffered by safety nets, can be easily reconciled with democratic political systems that distribute recognition based on citizenship. Faith in the constitution as a collective learning project oriented toward greater inclusion and freedom seems just as unwarranted: equal protection (civil rights) and robust negative freedom (civil liberties) more often than not conflict with each other and with the bureaucratic administration of welfare, health, and security (Habermas 1996). Nor does there exist a privileged standpoint within liberal democratic society for univocally grounding judgments about which policies enhance or hinder social freedom 
(Hedrick 2019). In the final analysis, advocates of recognition as a form of social freedom are left with the discomfiting thought that the modes of mediated recognition that exist in modern society promise little more than a possibility for partially reconciling ourselves to public institutions that selectively limit structural domination while never quite reconciling us to our social existence as a whole.

\section{Bibliography}

Allen, A. 2017. The End of Progress: Decolonizing the Normative Foundations of Critical Theory. New York, Columbia University Press.

Berlin, I. 1969. Four Essays on Freedom. Oxford. Oxford University Press.

Bohman, J. 2007. "Beyond Distributive Justice and Struggles for Recognition: Freedom, Democracy, and Critical Theory." European Journal of Political Theory 6(3): 267-275. Habermas, J. 1996. Between Facts and Norms: Toward a Discourse Theory of Law and Democracy. Cambridge, MA. MIT Press.

Honneth, A. 2007a. Disrespect: The Normative Foundations of Critical Theory. Cambridge. Polity Press.

-----2007b. "Between Aristotle and Kant: Recognition and Moral Obligation," in Honneth (2007a), pp. 129-43.

---- 2007c. "Negative Freedom and Cultural Belonging: An Unhealthy Tension in the Political Philosophy of Isaiah Berlin, in Honneth (2007a), pp. 240-53.

-----2007d. "Post-Traditional Communities: A Conceptual Proposal," in Honneth (2007a), pp. 254- 62

------2012. The I in the We: Studies in the Theory of Recognition. Cambridge. Polity Press.

------2014. Freedoms Right: The Social Foundations of Democratic Life. New York. Columbia University Press.

-----2015. "Freedom, Solidarity, and Democracy: An Interview with Axel Honneth" (conducted by Morten Raffnsoe-Moller),"in J. Jakobsen and O. Lysaker (eds.) Freedom and Recognition. Brill.

Ingram, D. 2020. “When Microcredit Doesn't Empower Women: Recognition Theories Contribution to the Debate Over Adaptive Preferences, in G. Schweiger (ed.), Poverty and Recognition. Springer.

------ 2018. World Crisis and Underdevelopment: A Critical Theory of Poverty, Agency, and Coercion. Cambridge. Cambridge University Press.

Marx, K. 1994a. "Critique of Hegel's Philosophy of Right," in J. O'Malley (ed.), Early Political Writings. Cambridge. Cambridge University Press, pp. 1-27.

------1994b. “on the Jewish Question," in Early Political Writings, pp. 28-56. 